\title{
CORRELATION \\ BETWEEN CONCENTRATION OF AIR POLLUTANTS AND OCCURRENCE OF CARDIAC ARRHYTHMIAS IN A REGION WITH HUMID CONTINENTAL CLIMATE
}

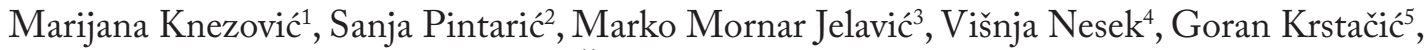 \\ Mislav Vrsalović ${ }^{5}$, Aljoša Šikić ${ }^{1}$, Ivan Zeljković ${ }^{1}$ and Hrvoje Pintarićc
}

\begin{abstract}
${ }^{1}$ Sestre milosrdnice University Hospital Center; ${ }^{2}$ First School of Economics; ${ }^{3}$ Department of Internal Medicine and Dialysis, Zagreb-East Health Center; ${ }^{4}$ Sveti Duh University Hospital, Zagreb, Osijek School of Medicine, Josip Juraj Strossmayer University of Osijek, Osijek; ${ }^{5}$ Institute for Cardiovascular Prevention and Rehabilitation, Zagreb, Osijek School of Medicine, Josip Juraj Strossmayer University of Osijek, Osijek; ${ }^{6}$ Sestre milosrdnice University Hospital Center, School of Dental Medicine, University of Zagreb, Zagreb, Croatia
\end{abstract}

SUMMARY - In this study, we investigated the correlation of air temperature, pressure and concentration of air pollutants with the rate of admissions for cardiac arrhythmias at two clinical centers in the area with a humid continental climate. This retrospective study included 3749 patients with arrhythmias admitted to emergency department (ED). They were classified into four groups: supraventricular tachycardia (SVT), ventricular tachycardia (VT), atrial fibrillation/undulation (Afib/ Aund), and palpitations (with no ECG changes, or with sinus tachycardia and extrasystoles). The number of patients, values of meteorological parameters (average daily values of air temperature, pressure and relative humidity) and concentrations of air pollutants (particles of dimensions $~ 10$ micrometers or less $\left(\mathrm{PM}_{10}\right)$, ozone $\left(\mathrm{O}_{3}\right)$ and nitrogen dioxide $\left.\left(\mathrm{NO}_{2}\right)\right)$ were collected during a two-year period (July 2008-June 2010). There were 1650 (44.0\%), 1525 (40.7\%), 451 (12.0\%) and 123 (3.3\%) patients with palpitations, Afib/Aund, SVT and VT, respectively. Spearman's correlation yielded positive correlation between the occurrence of arrhythmias and air humidity on the day $(r=0.07)$, and $1(r=0.08), 2(r=0.09)$ and 3 days before $(r=0.09)$, and $\mathrm{NO}_{2}$ particles on the day $(r=0.08)$ of ED admission; palpitations and air humidity on the day $(r=0.11)$, and $1(r=0.09), 2(r=0.07)$ and 3 days before $(r=0.10)$, and $\mathrm{PM}_{10}(r=0.11)$ and $\mathrm{NO}_{2}(r=0.08)$ particles on the day of $\mathrm{ED}$ admission; and Afib/Aund and air humidity 2 days before $(r=0.08) \mathrm{ED}$ admission ( $\mathrm{p}<0.05$ all). In conclusion, there was a very weak positive correlation of the occurrence of cardiac arrhythmias with air humidity and concentration of air pollutants in the region with a humid continental climate.

Key words: Air pollution - adverse effects; Arrhythmias, cardiac; Climate - adverse effects; Emergency service, hospital

\section{Introduction}

Air pollutants are a heterogeneous and complex mixture of gases, liquids and particulate matter, which

\footnotetext{
Correspondence to: Marko Mornar Jelavic, MD, Department of Internal Medicine and Dialysis, Zagreb-East Health Center, Ninska 10, HR-10000 Zagreb, Croatia

E-mail: mjelavic@yahoo.com

Received October 14, 2016, accepted November 7, 2016
}

are related to an increased risk of adverse cardiovascu$\operatorname{lar}(\mathrm{CV})$ events $^{1-3}$. Furthermore, air pollution poses a great health risk even in developed countries with legally defined thresholds of air pollution ${ }^{4-6}$. Air pollution is associated with an increased risk of various types of cardiac arrhythmias ${ }^{7-11}$, as a consequence of changes in the automation or conduction of impulses that can occur in all parts and systems of the heart ${ }^{12}$. 
They are common in clinical practice. An arrhythmia may in some people lead to significant symptoms and hemodynamic effects (palpitations, hypotension, dizziness, syncope, heart failure, angina attacks, etc.), and sometimes sudden death. Other patients may be asymptomatic or have minimal symptoms. The arrhythmias that occur in a diseased heart have a prognostic importance $^{12}$.

Zagreb is the capital and the largest city of the Republic of Croatia, which is located in south-eastern Europe $^{13}$. The wider Zagreb metropolitan area has a total population of up to 1.2 million ( $20 \%$ of the total Croatia's population). The climate of Zagreb is classified as a humid continental. The average daily mean temperature in winter is around $+1{ }^{\circ} \mathrm{C}$ (from December to February) and the average temperature in summer is $22.0{ }^{\circ} \mathrm{C}$.

In this study, we investigated the correlation between air temperature, pressure, concentration of air pollutants and the rate of admissions for cardiac arrhythmias in two clinical centers in the area with a humid continental climate.

\section{Patients and Methods}

This two-center retrospective study included 3749 consecutive patients admitted to emergency department (ED; Sestre milosrdnice University Hospital Center and Sveti Duh University Hospital) during a two-year period (June 2008-July 2010). All patients with arrhythmia as a primary diagnosis and living in Zagreb were included. Information on daily ED visits were collected retrospectively from the two hospital information systems. The study was approved by Ethics Committees of the two hospitals. All patient data were used without personal identifiers. Arrhythmias were diagnosed by using electrocardiography (ECG) and classified into four groups: supraventricular tachycardia (SVT), ventricular tachycardia (VT), atrial fibrillation/undulation (Afib/Aund), and palpitations (with no ECG changes, or with sinus tachycardia and extrasystoles). The concentrations of nitrogen dioxide $\left(\mathrm{NO}_{2}\right)$, ozone $\left(\mathrm{O}_{3}\right)$ and particles of dimensions $~ 10$ micrometers or less $\left(\mathrm{PM}_{10}\right)$ were collected by the $\mathrm{Na}-$ tional Monitoring Station Zagreb 1 (Enviromental Protection Agency). The mean daily values of air temperature $\left({ }^{\circ} \mathrm{C}\right)$, pressure $(\mathrm{kPa})$ and relative humidity $(\%)$ were collected by the Meteorological and Hydrological Service of Croatia.

\section{Statistical analysis}

Qualitative data were presented as absolute number and percentage. We used $\chi^{2}$-test with Yates correction for analysis. Quantitative data were presented as median and range. Differences between two groups and among three or more groups were tested by MannWhitney U-test and Kruskal-Wallis ANOVA test, respectively. The correlation between the number of patients with arrhythmias, values of meteorological parameters and concentrations of air pollutants was assessed by nonparametric Spearman's correlation test. It was classified by Spearman's $r$ values as very weak (0$0.19)$, weak (0.20-0.39), moderate (0.40-0.59), strong (0.60-0.79) and very strong (0.80-1.0) correlation. The level of statistical significance was set at $\alpha=0.05$. Processing was done using the STATISTICA 6.0 for Windows software (Dell Software, StatSoft Inc., Tulsa, USA).

\section{Results}

Of the total of 3749 patients, there were 1650 (44.0\%), 1525 (40.7\%), 451 (12.0\%) and 123 (3.3\%) patients with palpitations, Afib/Aund, SVT and VT, respectively (Fig. 1). The occurrence of palpitations, Afib/Aund and SVT was higher in females, and of VT in males (Fig. 1). Age differences between males and females according to type of arrhythmia are shown in Table 1. Females with Afib/Aund were significantly older (median age 73 vs. 66 years, $\mathrm{p}<0.001$ ).

During the study period, the mean daily values of $\mathrm{NO}_{2}\left(25.9(1.7-89.7) \mu \mathrm{g} / \mathrm{m}^{3}\right), \mathrm{O}_{3}(47.1(4.7-135.4) \mu \mathrm{g} /$

Table 1. Age differences between males and females according to type of arrbythmia

\begin{tabular}{|l|l|l|l|}
\hline Diagnosis & Males $^{\dagger}$ & Females & \\
\hline SVT & $56(16-89)$ & $\begin{array}{l}\text { Mann- } \\
\text { Whitney } \\
\text { U test }^{\ddagger}\end{array}$ \\
VT & $69(23-89)$ & $69(28-91)$ & $\mathrm{p}=0.066$ \\
$\mathrm{p}=0.967$ \\
Palpitations & $47(15-88)$ & $46(13-100)$ & $\mathrm{p}=0.568$ \\
Afib/Aund & $66(24-92)$ & $73(14-92)$ & $\mathrm{p}=0.000$ \\
Kruskal-Wallis & $\mathrm{p}=0.000$ & $\mathrm{p}=0.000$ & \\
ANOVA $^{\ddagger}$ & & \\
\hline
\end{tabular}

Afib/Aund = atrial fibrillation/atrial undulation; SVT = supraventricular tachycardia; $\mathrm{VT}=$ ventricular tachycardia; ${ }^{\dagger}$ data are presented as median and range; ${ }^{*}$ statistical significance at $\mathrm{p}<0.05$ 


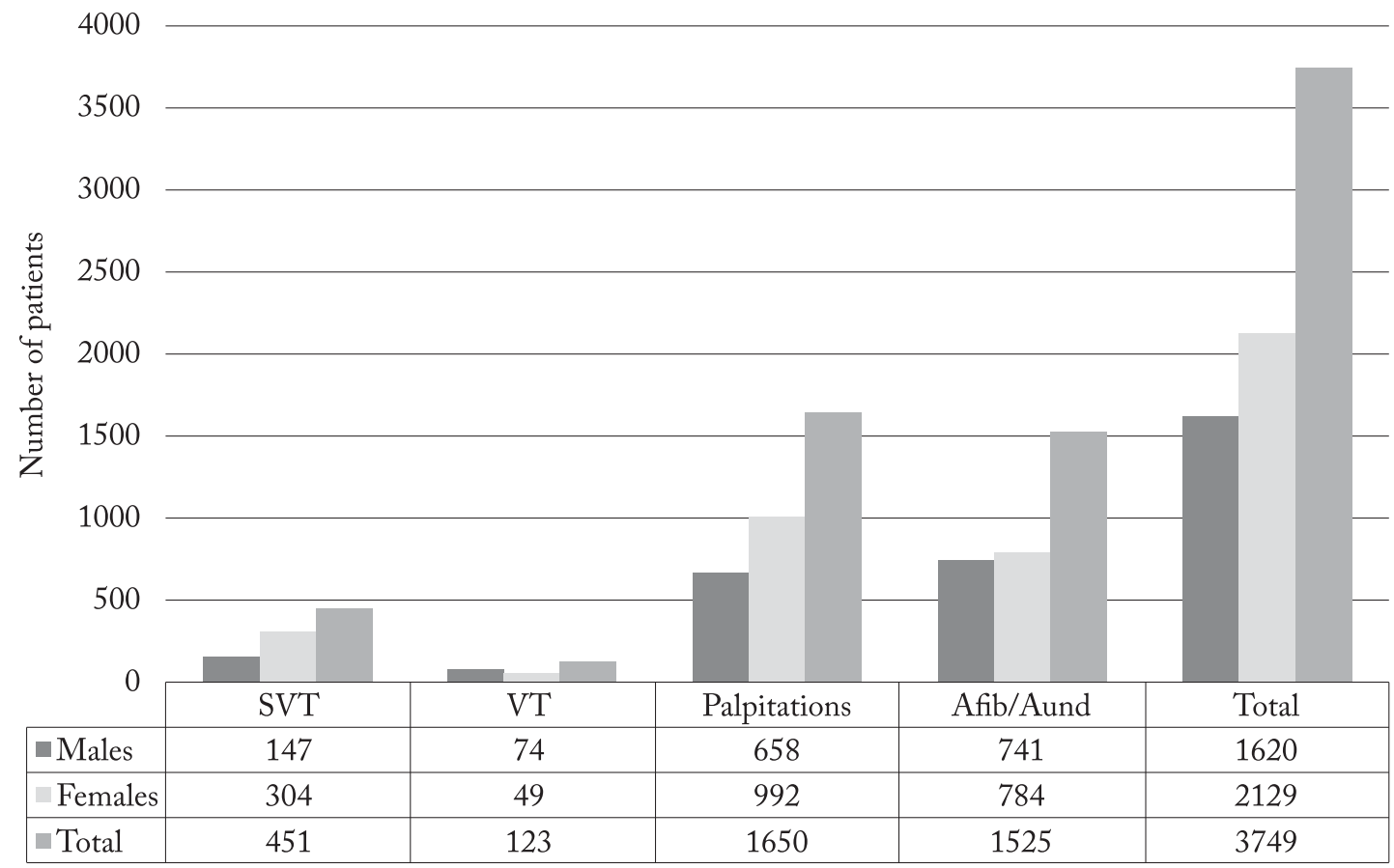

$\mathrm{SVT}=$ supraventricular tachycardia; VT = ventricular tachycardia; Afib/Aund $=$ atrial fibrillation/atrial undulation

Fig. 1. Number of patients with different arrhythmias admitted to emergency department during a two-year period (July 2008-June 2010).

Table 2. Correlation between meteorological parameters and occurrence of all arrhythmias (July 2008-June 2010)

\begin{tabular}{|l|l|l|l|l|l|l|l|}
\hline Parameter & Days & $\begin{array}{l}\text { Arrhythmias } \\
\text { (total) }(\mathrm{r})\end{array}$ & $\mathrm{p}^{\dagger}$ & $\begin{array}{l}\text { Arrhythmias } \\
\text { (males) (r) }\end{array}$ & $\mathrm{p}$ & $\begin{array}{l}\text { Arrhythmias } \\
\text { (females) }(\mathrm{r})\end{array}$ & $\mathrm{p}$ \\
\hline Temperature (Day 0) & 730 & -0.01 & 0.834 & -0.01 & 0.879 & -0.01 & 0.831 \\
Temperature (Day 1) & 730 & -0.01 & 0.749 & 0.00 & 0.999 & -0.02 & 0.617 \\
Temperature (Day 2) & 730 & -0.02 & 0.566 & -0.01 & 0.871 & -0.03 & 0.456 \\
Temperature (Day 3) & 730 & -0.03 & 0.412 & -0.02 & 0.663 & -0.04 & 0.341 \\
Pressure (Day 0) & 730 & -0.03 & 0.360 & -0.03 & 0.361 & -0.04 & 0.304 \\
Pressure (Day 1) & 730 & -0.04 & 0.265 & -0.04 & 0.245 & -0.03 & 0.391 \\
Pressure (Day 2) & 730 & -0.01 & 0.765 & 0.01 & 0.805 & -0.03 & 0.405 \\
Pressure (Day 3) & 730 & -0.03 & 0.384 & -0.01 & 0.748 & -0.04 & 0.273 \\
Humidity (Day 0) & 730 & 0.07 & $\mathbf{0 . 0 4 6}$ & 0.04 & 0.236 & 0.06 & 0.105 \\
Humidity (Day 1) & 730 & 0.08 & $\mathbf{0 . 0 2 8}$ & 0.04 & 0.339 & 0.09 & $\mathbf{0 . 0 2 1}$ \\
Humidity (Day 2) & 730 & 0.09 & $\mathbf{0 . 0 1 2}$ & -0.00 & 0.919 & 0.13 & $\mathbf{0 . 0 0 1}$ \\
Humidity (Day 3) & 730 & 0.09 & $\mathbf{0 . 0 1 0}$ & 0.01 & 0.763 & 0.11 & $\mathbf{0 . 0 0 3}$ \\
\hline
\end{tabular}

Day 0 = day of hospital admission; days 1-3 = days before hospital admission; $\mathrm{r}=$ Spearman's rank order correlation coefficient; ${ }^{\dagger}$ statistical significance at $\mathrm{p}<0.05$

$\left.\mathrm{m}^{3}\right)$ and $\mathrm{PM}_{10}\left(25.7(4.6-146.6) \mu \mathrm{g} / \mathrm{m}^{3}\right)$ were below the legally defined thresholds. Considering the humid continental climate characteristics, the given mean daily values of air temperature $\left(13.4(-7.9-28.5){ }^{\circ} \mathrm{C}\right)$, relative humidity $(68.9(37.7-95.3) \%)$ and air pressure (996 (966-1020) kPa) were as expected. 
Table 3. Correlation between meteorological parameters and occurrence of particular arrbythmias (July 2008-June 2010)

\begin{tabular}{|l|l|l|l|l|l|l|l|l|l|}
\hline Parameter & Days & $\begin{array}{l}\text { SVT } \\
\text { (r) }\end{array}$ & $\mathrm{p}^{\dagger}$ & $\begin{array}{l}\text { VT } \\
\text { (r) }\end{array}$ & $\mathrm{p}$ & $\begin{array}{l}\text { Palpitations } \\
(\mathrm{r})\end{array}$ & $\mathrm{P}$ & $\begin{array}{l}\text { Afib/ } \\
\text { Aund } \\
(\mathrm{r})\end{array}$ & $\mathrm{p}$ \\
\hline Temperature (Day 0) & 730 & -0.02 & 0.522 & 0.01 & 0.880 & -0.00 & 0.963 & -0.02 & 0.503 \\
Temperature (Day 1) & 730 & -0.03 & 0.355 & 0.01 & 0.759 & -0.01 & 0.865 & -0.02 & 0.606 \\
Temperature (Day 2) & 730 & -0.04 & 0.288 & 0.01 & 0.737 & -0.01 & 0.876 & -0.03 & 0.386 \\
Temperature (Day 3) & 730 & -0.04 & 0.319 & 0.01 & 0.878 & -0.02 & 0.518 & -0.03 & 0.477 \\
Pressure (Day 0) & 730 & -0.04 & 0.327 & -0.01 & 0.864 & 0.01 & 0.797 & -0.06 & 0.084 \\
Pressure (Day 1) & 730 & -0.05 & 0.141 & -0.04 & 0.236 & 0.01 & 0.756 & -0.05 & 0.174 \\
Pressure (Day 2) & 730 & -0.03 & 0.447 & -0.04 & 0.331 & 0.01 & 0.668 & -0.02 & 0.641 \\
Pressure (Day 3) & 730 & -0.01 & 0.749 & 0.01 & 0.762 & -0.00 & 0.897 & -0.04 & 0.269 \\
Humidity (Day 0) & 730 & 0.00 & 0.908 & -0.04 & 0.283 & 0.11 & $\mathbf{0 . 0 0 4}$ & 0.05 & 0.162 \\
Humidity (Day 1) & 730 & 0.02 & 0.619 & -0.00 & 0.921 & 0.09 & $\mathbf{0 . 0 1 3}$ & 0.05 & 0.169 \\
Humidity (Day 2) & 730 & 0.04 & 0.332 & -0.02 & 0.683 & 0.07 & $\mathbf{0 . 0 4 7}$ & 0.08 & $\mathbf{0 . 0 3 2}$ \\
Humidity (Day 3) & 730 & 0.02 & 0.680 & -0.01 & 0.693 & 0.10 & $\mathbf{0 . 0 0 9}$ & 0.06 & 0.093 \\
\hline
\end{tabular}

Day 0 = day of hospital admission; Days 1-3 = days before hospital admission; Afib/Aund = atrial fibrillation/atrial undulation; SVT = supraventricular tachycardia; VT = ventricular tachycardia; $r$ = Spearman's rank order correlation coefficient; ${ }^{\dagger}$ statistical significance at $\mathrm{p}<0.05$

We found no correlation between the occurrence of arrhythmias and air temperature and pressure, but there was positive correlation with air humidity on the day $(r=0.07)$, and $1(r=0.08), 2(r=0.09)$ and 3 days $(r=0.09)$ before ED admission, especially in females $(\mathrm{p}<0.05$ all) (Table 2). The occurrence of palpitations showed positive correlation with air humidity on the day $(r=0.11)$, and $1(r=0.09), 2(r=0.07)$ and $3(r=0.10)$ days before ED admission; and the occurrence of Afib/ Aund showed positive correlation with air humidity 2 days $(r=0.08)$ before ED admission ( $\mathrm{p}<0.05$ all) (Table $3)$. On the day of ED admission, the occurrence of arrhythmias yielded positive correlation with the concentration of $\mathrm{NO}_{2}$ particles $(r=0.08)$ and the occurrence of palpitations with the concentration of $\mathrm{PM}_{10}$ $(r=0.11)$ and $\mathrm{NO}_{2}(r=0.08)$ particles $(\mathrm{p}<0.05$ all $)(\mathrm{Ta}-$ bles 4 and 5).

\section{Discussion}

This study investigated the correlation of air temperature, pressure, concentration of air pollutants with the rate of admissions for cardiac arrhythmias at two clinical centers in the area with a humid continental climate. There was a very weak positive correlation of the number of cases with arrhythmias with air humidity and concentration of $\mathrm{NO}_{2}$ and $\mathrm{PM}_{10}$ particles. It should be noted that daily concentrations of air pollutants were below the permissible exposure limits during the study period. Nguyen et al. found negative association between air temperature and occurrence of Afib ${ }^{14}$. Gluszak et al. report no association between air temperature, pressure, or relative humidity, and occurrence of Afib ${ }^{15}$. Other authors found positive association between relative humidity, air pressure and occurrence of arrhythmias, SVT and ventricular extrasytoles ${ }^{16-19}$.

In our study, the appearance of arrhythmias showed a very weak positive correlation with air humidity, especially in females. The possible explanation may be impaired perspiration and overall thermoregulation during the period of raising moisture, and it may gradually burden the less capable cardiovascular system beyond its adaptive ability. It is possible that women have less efficient thermoregulatory and sweating mechanisms ${ }^{20}$. The absence of correlation with air temperature and pressure may be explained by the characteristics of our climate, as well as cooperation of hydrometeorology services and media, which has strong influence on informing the population about weather conditions; citizens are informed on daily basis how to 
Table 4. Correlation between air pollution and occurrence of all arrbythmias (July 2008-June 2010)

\begin{tabular}{|l|l|l|l|l|l|l|l|}
\hline Parameter & Days & $\begin{array}{l}\text { Arrhythmias } \\
(r)\end{array}$ & $\mathrm{p}^{\dagger}$ & $\begin{array}{l}\text { Arrhythmias } \\
\text { (males) }(\mathrm{r})\end{array}$ & $\mathrm{p}$ & $\begin{array}{l}\text { Arrhythmias } \\
\text { (females) }(\mathrm{r})\end{array}$ & $\mathrm{p}$ \\
\hline $\mathrm{PM}_{10}$ (Day 0) & 720 & 0.06 & 0.117 & 0.02 & 0.514 & 0.05 & 0.202 \\
$\mathrm{PM}_{10}$ (Day 1) & 719 & 0.02 & 0.526 & 0.06 & 0.097 & -0.02 & 0.591 \\
$\mathrm{PM}_{10}$ (Day 2) & 718 & -0.00 & 0.959 & 0.04 & 0.302 & -0.02 & 0.610 \\
$\mathrm{PM}_{10}$ (Day 3) & 717 & -0.00 & 0.930 & -0.01 & 0.862 & 0.00 & 0.901 \\
$\mathrm{NO}_{2}$ (Day 0) & 692 & 0.08 & $\mathbf{0 . 0 3 2}$ & 0.04 & 0.297 & 0.07 & 0.065 \\
$\mathrm{NO}_{2}$ (Day 1) & 692 & 0.07 & 0.075 & 0.06 & 0.098 & 0.04 & 0.248 \\
$\mathrm{NO}_{2}$ (Day 2) & 692 & 0.02 & 0.520 & 0.03 & 0.370 & 0.02 & 0.555 \\
$\mathrm{NO}_{2}$ (Day 3) & 692 & 0.00 & 0.950 & -0.00 & 0.918 & 0.02 & 0.670 \\
$\mathrm{O}_{3}$ (Day 0) & 646 & -0.03 & 0.417 & 0.01 & 0.807 & -0.05 & 0.247 \\
$\mathrm{O}_{3}$ (Day 1) & 646 & -0.04 & 0.266 & -0.03 & 0.510 & -0.04 & 0.297 \\
$\mathrm{O}_{3}$ (Day 2) & 646 & -0.04 & 0.297 & -0.01 & 0.864 & -0.07 & 0.083 \\
$\mathrm{O}_{3}$ (Day 3) & 646 & -0.00 & 0.902 & 0.02 & 0.536 & -0.03 & 0.469 \\
\hline
\end{tabular}

Day 0 = day of hospital admission; Days 1-3 = days before hospital admission; $\mathrm{PM}_{10}=$ particles of dimensions $\sim 10$ micrometers or less; $\mathrm{O}_{3}$ = ozone; $\mathrm{NO}_{2}=$ nitrogen dioxide; $\mathrm{r}=$ Spearman's rank order correlation coefficient; ${ }^{\dagger}$ statistical significance at $\mathrm{p}<0.05$

Table 5. Correlation between air pollution and occurrence of particular arrhythmias (July 2008-June 2010)

\begin{tabular}{|l|l|l|l|l|l|l|l|l|l|}
\hline Parameter & Days & $\begin{array}{l}\text { SVT } \\
(r)\end{array}$ & $\mathrm{p}^{\dagger}$ & $\begin{array}{l}\text { VT } \\
(\mathrm{r})\end{array}$ & $\mathrm{p}$ & $\begin{array}{l}\text { Palpitations } \\
(\mathrm{r})\end{array}$ & $\mathrm{p}$ & $\begin{array}{l}\text { Afib/ } \\
\text { Aund (r) }\end{array}$ & $\mathrm{p}$ \\
\hline $\mathrm{PM}_{10}$ (Day 0) & 730 & 0.03 & 0.454 & -0.02 & 0.574 & 0.11 & $\mathbf{0 . 0 0 3}$ & -0.03 & 0.373 \\
$\mathrm{PM}_{10}$ (Day 1) & 730 & -0.00 & 0.983 & -0.01 & 0.875 & 0.07 & 0.053 & -0.02 & 0.506 \\
$\mathrm{PM}_{10}$ (Day 2) & 730 & 0.02 & 0.543 & 0.02 & 0.630 & 0.03 & 0.881 & -0.02 & 0.593 \\
$\mathrm{PM}_{10}$ (Day 3) & 730 & 0.03 & 0.377 & 0.02 & 0.674 & 0.03 & 0.356 & -0.04 & 0.325 \\
$\mathrm{NO}_{2}$ (Day 0) & 730 & 0.01 & 0.831 & 0.01 & 0.847 & 0.08 & $\mathbf{0 . 0 3 8}$ & 0.03 & 0.476 \\
$\mathrm{NO}_{2}$ (Day 1) & 730 & 0.00 & 0.989 & 0.04 & 0.279 & 0.07 & 0.060 & 0.04 & 0.328 \\
$\mathrm{NO}_{2}$ (Day 2) & 730 & 0.04 & 0.250 & 0.03 & 0.497 & 0.05 & 0.200 & -0.02 & 0.678 \\
$\mathrm{NO}_{2}$ (Day 3) & 730 & 0.01 & 0.701 & 0.00 & 0.908 & 0.06 & 0.090 & -0.06 & 0.146 \\
$\mathrm{O}_{3}$ (Day 0) & 730 & -0.00 & 0.997 & 0.02 & 0.687 & -0.05 & 0.176 & -0.03 & 0.505 \\
$\mathrm{O}_{3}$ (Day 1) & 730 & -0.00 & 0.966 & -0.00 & 0.936 & -0.04 & 0.365 & -0.06 & 0.138 \\
$\mathrm{O}_{3}$ (Day 2) & 730 & 0.01 & 0.844 & 0.02 & 0.652 & -0.05 & 0.179 & -0.07 & 0.082 \\
$\mathrm{O}_{3}$ (Day 3) & 730 & 0.02 & 0.656 & 0.03 & 0.504 & -0.05 & 0.179 & -0.01 & 0.833 \\
\hline
\end{tabular}

Day 0 = day of hospital admission; Days 1-3 = days before hospital admission; Afib/Aund = atrial fibrillation/atrial undulation; SVT = supraventricular tachycardia; $\mathrm{VT}=$ ventricular tachycardia; $\mathrm{PM}_{10}=$ particles of dimensions $\sim 10$ micrometers or less; $\mathrm{O}_{3}=$ ozone; $\mathrm{NO}_{2}=$ nitrogen dioxide; $r=$ Spearman's rank order correlation coefficient; ${ }^{\dagger}$ statistical significance at $\mathrm{p}<0.05$

prevent the impact of undesirable weather changes on their health.

Ozone is a secondary pollutant created indirectly from combustion engines; it is related to hospital admissions for cardiovascular and respiratory diseas$\mathrm{es}^{21-24}$. Several authors have reported positive associa- tion, whereas others found no association between arrhythmias and $\mathrm{O}_{3}$ particles ${ }^{25,26}$. These opposite findings may reflect individual susceptibility to arrhythmia because of the underlying heart disease. The same conclusion was made by the authors of a systematic review and meta-analysis of global association of air pollut- 
ants and heart failure ${ }^{27}$. Nitrogen dioxide is a primary pollutant and strong respiratory irritant mainly from outdoor sources including motor vehicles and fossilfuel power plants, whereas the most important indoor sources are gas heaters, stoves and tobacco smoke ${ }^{28}$. The number of patients admitted to ED correlates with the concentration of $\mathrm{NO}_{2}$ and $\mathrm{PM}_{10}$ particles $^{8,10,24,29-31}$, which have strong influence on cardiovascular morbidity and mortality. In this study, the number of patients with arrhythmias was in positive correlation with the concentration of $\mathrm{NO}_{2}$ and $\mathrm{PM}_{10}$ particles on the day of ED admission.

The results of the study should be viewed in the light of some limitations. The study period was rather short. Data on $\mathrm{O}_{3}$ were obtained from only one monitoring station, which may have led to misclassification of the exposure level. Moreover, there was the lack of precise exposure estimates at the individual level due to different daily activity patterns and local mobility of each patient. There are many factors that may influence the rate of admissions for cardiac arrhythmias that were not taken into account.

In conclusion, the occurrence of arrhythmias showed very weak positive correlation with air humidity and concentration of air pollutants in the area with a humid continental climate. However, the upper lawful limits of air pollutants should be additionally restricted. It is of utmost importance because the currently permissible air pollution level increases the number of patients presenting to ED.

\section{References}

1. Brunekreef B, Holgate ST. Air pollution and health. Lancet. 2002;360:1233-42. http://dx.doi.org/10.1016/S0140-6736 (02)11274-8

2. Polichetti G, Cocco S, Spinali A, Trimarco V, Nunziata A. Effects of particulate matter $(\mathrm{PM}(10), \operatorname{PM}(2.5)$ and $\mathrm{PM}(1))$ on the cardiovascular system. Toxicology. 2009;261:1-8. http:// dx.doi.org/10.1016/j.tox.2009.04.035

3. Brook RD, Franklin B, Cascio W, Hong Y, Howard G, Lipsett M, et al.; Expert Panel on Population and Prevention Science of the American Heart Association. Air pollution and cardiovascular disease: a statement for healthcare professionals from the Expert Panel on Population and Prevention Science of the American Heart Association. Circulation. 2004;109:2655-71. https://doi.org/10.1161/01.CIR.0000128587.30041.C8

4. Kraft M, Eikmann T, Kappos A, Künzli N, Rapp R, Schneider $\mathrm{K}$, et al. The German view: effects of nitrogen dioxide on hu- man health - derivation of health-related short-term and longterm values. Int J Hyg Environ Health. 2005;208:305-18. http://dx.doi.org/10.1016/j.ijheh.2005.04.002

5. Samoli E, Aga E, Touloumi G, Nisiotis K, Forsberg B, Lefranc A, et al. Short-term effects of nitrogen dioxide on mortality: an analysis within the APHEA project. Eur Respir J. 2006;27: 1129-38. https://doi.org/10.1183/09031936.06.00143905

6. Wong CM, Ma S, Hedley AJ, Lam TH. Does ozone have any effect on daily hospital admissions for circulatory diseases? J Epidemiol Community Health. 1999;53:580-1. http://dx.doi. org/10.1136/jech.53.9.580

7. Link MS, Dockery DW. Air pollution and the triggering of cardiac arrhythmias. Curr Opin Cardiol. 2010;25:16-22. https://dx.doi.org/10.1097/HCO.0b013e32833358cd

8. Peters A, Liu E, Verrier RL, Schwartz J, Gold DR, Mittleman $\mathrm{M}$, et al. Air pollution and incidence of cardiac arrhythmia. Epidemiology. 2000;11:11-7.

9. Rich DQ, Schwartz J, Mittleman MA, Link M, LuttmannGibson H, Catalano PJ, et al. Association of short-term ambient air pollution concentrations and ventricular arrhythmias. Am J Epidemiol. 2005;161:1123-32. https://doi.org/10.1093/ aje/kwi143

10. Santos UP, Terra-Filho M, Lin CA, Pereira LA, Vieira TC, Saldiva $\mathrm{PH}$, et al. Cardiac arrhythmia emergency room visits and environmental air pollution in Sao Paulo, Brazil. J Epidemiol Community Health. 2008;62:267-72. http://dx.doi. org/10.1136/jech.2006.058123

11. Sarnat SE, Suh HH, Coull BA, Schwartz J, Stone PH, Gold DR. Ambient particulate air pollution and cardiac arrhythmia in a panel of older adults in Steubenville, Ohio. Occup Environ Med.2006;63:700-6.https://doi.org/10.1136/oem.2006.027292

12. Pintarić H, Jelavić Mornar M. Arrhythmias and conduction disturbances in ischemic heart disease. Lijec Vjesn. 2016;138 (Suppl 1):46-53.

13. City of Zagreb. Zagreb in brief. The official City of Zagreb website, http://www.zagreb.hr/default.aspx?id=1125; 2014 [accessed 2014].

14. Nguyen JL, Link MS, Luttmann-Gibson H, Laden F, Schwartz J, Wessler BS, et al. Drier air, lower temperatures, and triggering of paroxysmal atrial fibrillation. Epidemiology. 2015;26:37480. https://doi.org/10.1097/EDE.0000000000000284

15. Głuszak A, Kocoń S, Zuk K, Aljabali P, Gluza A, Siwek K. Episodes of atrial fibrillation and meteorological conditions. Kardiol Pol. 2008;66:958-63.

16. Culic V, Silic N, Hodzic M. Triggering of supraventricular tachycardia by physical activity and meteorologic factors. Int J Cardiol. 2013;168:4295-300. https://doi.org/10.1016/j.ijcard. 2013.04.195

17. Culic V, Eterovic D, Miric D, Giunio L, Lukin A, Fabijanic D. Triggering of ventricular tachycardia by meteorologic and emotional stress: protective effect of beta-blockers and anxio- 
lytics in men and elderly. Am J Epidemiol. 2004;160:1047-58. https://doi.org/10.1093/aje/kwh335

18. Alberdi JC, Díaz J, Montero JC, Mirón I. Daily mortality in Madrid community 1986-1992: relationship with meteorological variables. Eur J Epidemiol. 1998;14:571-8.

19. Dilaveris P, Synetos A, Giannopoulos G, Gialafos E, Pantazis A, Stefanadis C. Climate impacts on myocardial infarction deaths in the Athens territory: the CLIMATE study. Heart. 2006;92:1747-51. http://dx.doi.org/10.1136/hrt.2006.091884

20. Bittel J, Henane R. Comparison of thermal exchanges in men and women under neutral and hot conditions. J Physiol. 1975;250:475-89.

21. O’Neill MS, Loomis D, Borja-Aburto VH. Ozone, area social conditions, and mortality in Mexico City. Environ Res. 2004;94:234-42. https://doi.org/10.1016/j.envres.2003.07.002

22. Koken PJ, Piver WT, Ye F, Elixhauser A, Olsen LM, Portier CJ. Temperature, air pollution, and hospitalization for cardiovascular diseases among elderly people in Denver. Environ Health Perspect. 2003;111:1312-7.

23. Gryparis A, Forsberg B, Katsouyanni K, Analitis A, Touloumi G, Schwartz J, et al. Acute effects of ozone on mortality from the Air Pollution and Health: a European Approach project. Am J Respir Crit Care Med. 2004;170:1080-7. https://doi. org/10.1164/rccm.200403-333OC

24. Pintaric S, Jelavic MM, Nesek V, Babic Z, Vrsalovic M, Knezovic M, Bielen J, Zeljkovic I, Pintaric H. The influence of air pollutants on appearance of acute myocardial infarction in the region with humid continental climate. Am J Emerg Med. 2016;34: 1679-82. http://dx.doi.org/10.1016/j.ajem.2016.04.054
25. Rich DQ, Mittleman MA, Link MS, Schwartz J, Gibson HL, Catalano PJ, et al. Increased risk of paroxysmal atrial fibrillation episodes associated with acute increases in ambient air pollution. Environ Health Perspect. 2006;114:120-3. https://dx.doi. org/10.1289/ehp. 8371

26. Langrish JP, Watts SJ, Hunter AJ, Shah AS, Bosson JA, Unosson J, et al. Controlled exposures to air pollutants and risk of cardiac arrhythmia. Environ Health Perspect. 2014;122:74753. https://doi.org/10.1289/ehp.1307337

27. Shah AS, Langrish JP, Nair H, McAllister DA, Hunter AL, Donaldson K, et al. Global association of air pollution and heart failure: a systematic review and meta-analysis. Lancet. 2013;382:1039-48. https://doi.org/10.1016/S0140-6736 (13)60898-3

28. Samoli E, Aga E, Touloumi G, Nisiotis K, Forsberg B, Lefranc $A$, et al. Short-term effects of nitrogen dioxide on mortality: an analysis within the APHEA project.EurRespirJ.2006;27:112938. https://doi.org/10.1183/09031936.06.00143905

29. Pintarić S, Zeljković I, Pehnec G, Nesek V, Vrsalović M, Pintarić H. Impact of meteorological parameters and air pollution on Emergency Department visits for cardiovascular diseases in the city area of Zagreb, Croatia. Acta Clin Croat. 2012;51:9-15.

30. Metzger KB, Tolbert PE, Klein M, Peel JL, Flanders WD, Todd K, et al. Ambient air pollution and cardiovascular emergency department visits. Epidemiology. 2004;15:46-56. https:// doi.org/10.1097/01.EDE.0000101748.28283.97

31. Schwartz J. Air pollution and hospital admissions for cardiovascular disease in Tucson. Epidemiology. 1997;8:371-7.

Sažetak

\title{
KORELACIJA IZMEĐU KONCENTRACIJE ONEČIŠĆIVAČA ZRAKA I POJAVNOSTI SRČANIH ARITMIJA U PODRUČJU S VLAŽNOM KONTINENTALNOM KLIMOM
}

\author{
M. Knezović, S. Pintarić, M. Mornar Jelavić, V. Nesek, G. Krstačic, M. Vrsalović, A. Šikić, I. Zeljković i H. Pintarić
}

U ovoj studiji istraživali smo korelaciju temperature zraka, tlaka zraka, koncentracije onečišćivača zraka i učestalosti srčanih aritmija u dva klinička centra u području s vlažnom kontinentalnom klimom. Retrospektivna studija je uključivala 3749 bolesnika s aritmijama primljenih u hitnu službu (HS). Oni su klasificirani u četiri skupine: supraventrikulska tahikardija (SVT), ventrikulska tahikardija (VT), atrijska fibrilacija/undulacija (Afib/Aund) i palpitacije (bez EKG promjena ili sa sinusnom tahikardijom i ekstrasistolama). Broj bolesnika, vrijednosti meteoroloških parametara (prosječne dnevne vrijednosti temperature zraka, tlaka i relativne vlage) i koncentracije onečišćujućih tvari u zraku (čestice dimenzija 10 mikrometara ili manje $\left(\mathrm{PM}_{10}\right)$, ozon $\left(\mathrm{O}_{3}\right)$ i dušikov dioksid $\left(\mathrm{NO}_{2}\right)$ ) prikupljene su tijekom dvije godine (srpanj 2008.-lipanj 2010.). Bilo je 1650 (44,0\%), 1525 (40,7\%), 451 (12,0\%) i 123 (3,3\%) bolesnika s palpitacijama, Afib/Aund-om, SVT-om odnosno VT-om. Primjenom Spearmanove analize našli smo pozitivnu korelaciju između pojave aritmije i vlažnosti zraka na dan $(\mathrm{r}=0,07), 1$ $(\mathrm{r}=0,08), 2(\mathrm{r}=0,09)$ i 3 dana prije $(\mathrm{r}=0,09)$ te $\mathrm{NO}_{2}$ čestica na dan $(\mathrm{r}=0,08)$ prijma u HS; palpitacija i vlažnosti zraka na dan $(\mathrm{r}=0,11), 1(\mathrm{r}=0,09), 2(\mathrm{r}=0,07)$ i 3 dana prije $(\mathrm{r}=0,10)$ te $\mathrm{PM}_{10}(\mathrm{r}=0,11)$ i NO $\mathrm{N}_{2}(\mathrm{r}=0,08)$ čestica na dan prijma u HS; Afib/Aund i vlažnosti zraka 2 dana prije $(\mathrm{r}=0,08)$ prijma u HS (za sve $\mathrm{p}<0,05)$. U zaključku, utvrđena je vrlo slaba pozitivna korelacija između pojavnosti srčanih aritmija i vlage u zraku te koncentracije onečišćivača zraka u području s vlažnom kontinentalnom klimom.

Ključne riječi: Onečǐscenost zraka - štetna djelovanja; Aritmije, srčane; Klima-štetna djelovanja; Hitna služba, bolnička 